\title{
Methodology to determine the value of a poultry farm
}

\author{
JCN Joubert ${ }^{1}$ and C E Cloete $^{1}$ \\ ${ }^{1}$ Department of Construction Economics \\ University of Pretoria \\ South Africa \\ E-mail: chris.cloete@up.ac.za
}

\begin{abstract}
:
Much uncertainty exists about the most useful method to value a poultry farm. The purpose of the research is to determine the method of valuation that is the most appropriate and reliable for the valuation of a broiler farm. A sample of 15 out of the 196 contract broiler farm valuations was selected in the Mpumalanga and North West provinces in South Africa. The size of the broiler houses was at least $1000 \mathrm{~m}^{2}$. Broiler units with a minimum of four houses were taken into account. Data was gathered by means of assessments of previous valuations as well as physical valuations done in the field and analysed statistically. Figures were tested for normality; differences between the overall means were determined by the analysis of variance using the ANOVA test; the correlation coefficients between the two different methods and the dependable variable were determined; and regression analysis was fitted. The differences in the coefficient of variance between the two sets of data used indicate that the cost approach has a smaller variation around the mean. The income approach, on the other hand, indicates a more realistic approach, because the basis is the net margin and not a norm for replacement and depreciation. Although differences do exist, a strong correlation exists between the two methods.
\end{abstract}

Keywords: Valuation methods, poultry farm, broiler units, valuation of broiler units.

\section{Introduction}

According to the National Agriculture Marketing Council (NAMC) (2007:5), South Africa produces more than $85 \%$ of the broiler meat in the Southern African Development Community (SADC) and occupies the 15th position globally in industry size, with a market share of $1.38 \%$, of the 202 countries listed for broiler production (SAPA, 2006:17). Ratcliff (2001:7) indicated that the world consumption is projected to rise on average by $1.5 \%$ per annum. Rothwell (2001:2) pointed out that the industry continued to grow at a pace that exceeded the growth of any other meat sector in the world, with world production forecast to increase annually between 2000 and 2009 by $2.4 \%$ and poultry net exports by $3.2 \%$, with high and increasing consumption rates.

The SA poultry industry continues to dominate the agricultural sector in South Africa. The turnover at the producer level for the year 2008, as recorded by the Department of Agriculture (DOA), was more than R24.6 billion, made up of R18.624 billion for broilers, R6.039 billion for eggs and R3.095 billion for the chick industry. At retail level the turnover amounts to R36.893 billion (SAPA, 2009:5). 
Broiler operations are highly capital-intensive and need a high level of technical expertise. Trained management skills are important factors for a successful operation. A thorough knowledge and understanding of valuation methodology and the broiler operation are critical when it comes to the valuation of broiler units.

The purpose of this research was to assess and compare the different methods used for the valuation of contract broiler producers.

\section{Literature survey}

Although extensive literature exists on valuation in general and on agricultural valuations in particular (e.g. Behrmann, 1995; Clark and Litt, 1973; Coetzee and Steyn, 2004; Green, 1995; Griffiths, 2005; Herholdt, 2004; Murray, 1973; Suter, 1981), limited material exists on the valuation of broiler units. Various publications, discussions with informed individuals, broiler farmers, contractors, financial institutions, valuers in practice, agricultural advisors and the Internet served as valuable tools of research.

Three well-known types of appraisals are commonly used in practice when valuing agricultural land in South Africa (Suter, 1981:249). Agricultural land has special characteristics that set it apart from other types of property.

The three approaches to the valuation of property commonly used in South

Africa are:

- the comparable sales (or market) approach,

- the income capitalised (or indirect) approach, and

- the cost approach.

These methods are briefly described as follows:

\subsection{Comparable-sales or market approach}

This method is based on the prices paid for other farm properties located in the same area and which have recently changed ownership (Suter, 1981:249). The International Valuation Standards (IVS), as defined by Marten (2001:5) and accepted by the South African Council of Valuers, define the comparable-sales or market approach as follows:

The estimate amount for which an asset (since changed to "property") should exchange on the date of valuation between a willing buyer and a willing seller, in an arm's length transaction after proper marketing, wherein the parties had each acted knowledgeable, prudently and without compulsion.

A comparable sale is defined as a farm or property which resembles the subject property being appraised as closely as possible, in terms of the kind of farm organisation, type of farm, date of sale, location, farm size, productive capacity and extent of improvements (Behrmann, 1995:12). Behrmann (1995:14) also mentions that value adjustments are typically made for the following factors: 
(1) date of transaction;

(2) location;

(3) farm size;

(4) productive capacity;

(5) extent of the improvements; and

(6) other factors, like methods of sale.

Positive or negative adjustments for each major factor are generally applied to each comparable sale. Because a farm sold seldom fully reflects the maximum or difference in value in money terms due to any major factors, the figures derived may be discounted or reduced, depending on the extent to which that factor may have influenced the sale price.

Coetzee and Steyn (2004:13) state that investors, as well as legalists, favour the comparable-sales method of valuation. Sales in broiler units are limited and, if detected, differences in broiler house technology play a major role in determining the net margin of a broiler unit.

The difficulty is that broiler farms are limited and that comparable sales are very scarce.

Schimmel (in National Property Education Committee, 2004:32) stresses the following:

One of the difficulties of valuation is that sufficient data generally does not exist, and if it does and the sales are only somewhat similar, a number of adjustments are required, for example, those for the time, location, or physical condition of the properties. The danger lies in the fact that the more adjustments you make, the less comparable the properties become, until one adjusts the property right out of comparability. The second problem arises when adjustments are made. It is easy enough to recognise a difference in location, size or shape, however, the difficult part is to put a monetary value to all of these items.

\subsection{Income-capitalised or indirect approach}

Suter (1981:249) defines the income capitalised approach as follows:

The earnings or income capitalization approach in which value is based on the annual income stream that the farm or subject property will almost likely produce in the future.

The National Property Education Committee (2004:32) points out that the income capitalised method of valuation is founded on the hypothesis that a purchaser/investor would pay no more for a property with a predetermined income stream than he would pay for a similar property with the same predetermined income stream, all factors (including, most importantly, the risk factors) being equal.

Agricultural land has value because investors expect that land will yield profits in future years. The price of land is also affected by inflationary expectations and expectations of 
mortgage rates. The difference between the latter is called the real discount rate (Nieuwoudt, 1995:1).

Coetzee and Steyn (2004:13) claim that earnings and the capitalisation rate respond to inflation by the same ratio, i.e. if the inflation rate is $5 \%$, the returns from the farming operation or rent and the capitalisation rate would respond equally. The formula is as follows:

$$
V_{0}=\frac{P_{0}}{i_{i}}
$$

where:

$V_{0}$ is the present productive value of the farm;

$\boldsymbol{P}_{0}$ is the real earnings from the farm; and

$i_{t}$ is the real capitalisation rate.

Behrmann (1995:19) proposed that the quickest and easiest method of capitalizing residual money returns to land into value is with a cash lease. If cash leases are to be used in order to derive a capitalisation rate, they may be used if a sufficient number of leases are observed in relation to the market value of the farm land. If this is possible, a sound objective rate of capitalisation may be derived. At the same time, a valuer has to be sure that the lease figure he/she uses is the net figure, that is, after the landlord's expenses are deducted from the total lease payment.

Once the annual net income of a farm has been estimated, it is relatively easy to compute either an independent income value or sale value estimate by capitalisation. The main problems are an understanding of the capitalization concept and the selection of a capitalisation rate.

Conceptually, the capitalisation rate is the opportunity cost of money to whoever are the most likely buyers or owners of the subject property. The rate reflects that yield which could be obtained on a comparable investment by the most likely buyer or owner, if he/she were to invest, not in farm real estate or in the subject property, but in the next best alternative opportunity in the community instead (Behrmann,1995:20).

Behrmann (1995:21) states that determination of an appropriate capitalization rate requires the best judgement from even the most experienced farm appraiser.

The broiler industry is a highly specialised biological factory that needs very good management skills. The industry provides an equal cash flow stream on an annual basis. The value is a function of the rent it can generate. From research on the various valuation methods, it is evident that the income-capitalised approach can be applied with great success on a broiler farm.

\subsection{Cost approach}

The value determined by the cost approach is based on the sum of values contributed by the various acreages of different quality of land, as though unimproved, and each of the 
buildings and improvements (Suter, 1981:249). Suter (1981:367) also makes the comment that most people are assumed to be rational, in which case they would willingly pay no more for an item than the cost of an acceptable replacement or substitute.

This statement is supported by the National Property Education Committee (2004:33):

The cost method is founded on the hypothesis that a person would pay no more for a property than the cost of erecting a new structure on a comparable piece of land. In essence, the current cost of replacing the structure, minus an allowance for structural, functional design and economic depreciation, is added to the value of the land as if it was vacant. While the value of the land is determined as if vacant, it is valued with reference to its existing use and not with reference to its 'highest and best' use.

Suter (1981:376) stipulated that the cost approach typically leads to a value somewhat higher than the earnings or sale approach. It does not establish value in the market; however, it does tend to establish an upper limit to that value and it serves as a check against the other approaches. The cost approach, as applied to various components of a farm property, is most useful when the subject farm, if it were to be sold, would probably be sold in separate tracts and for separate uses.

Green (1995:28) says that the cost approach is the most popular approach to value buildings on a farm. Certain infrastructure would always be necessary on a farm, like roads, fences, barns and water tanks. If these features are not present, normal operation cannot continue. However, this does not necessarily enhance the value of the infrastructure itself. Several values may therefore be ascribed to a building or a group of buildings.

Behrmann (1995:32) states that some of the reasons that the sum of the parts might be greater than the whole are that:

- in many areas of agriculture there is a strong demand for unimproved land;

- the cost of new improvements seldom, if ever, adds an equal value to the market value of the farm;

- new technology often adds to the efficiency of the farm without making an equal or proportional contribution to the farm's market value;

- a number of investments in buildings and improvements are sometimes based on wants rather than needs, and a prospective buyer's own wants would influence his judgments and valuation; and

- farming operations may experience years of high and low income alternately, and in the years of high income the owner may over-invest in equipment and improvements. Hence, the appraiser may underestimate the depreciation of such assets.

Cost is not necessarily value. If an item can be reproduced or replaced, the cost of acquiring that particular item, or an equally desirable substitute, tends to establish an upper limit to the value. Cost represents that upper limit only if several assumptions are made, namely (Behrmann, 1995:33): 
- The existing item is one that can actually and easily be replaced. It cannot remain an old-fashioned or obsolete building. It has to be one that can be replaced by a modern building, with modern material and equipment and erected by modern techniques.

- The item can be created, or a substitute acquired, without costly delay. In some instances, a buyer would pay more than the cost of the item, and justify it, in order to own or obtain it immediately.

- Following the creation of the asset, no particular physical deterioration should have occurred. In practice, some is likely to occur and this is a function of time, which cannot remain constant.

The infrastructure on a specialised farming unit is of the utmost importance. Normally, without the infrastructure, farming operations cannot continue. The type and state of technology invested also play an important role - a fully environmentally controlled broiler house is more productive and efficient than a semi-environmentally controlled broiler house. The technology of the house can determine the outcome of the growing rate of broilers and can have an influence on mortality, etc. In a specialised farming operation, infrastructure can be divided into essential infrastructure and complementary infrastructure.

The final question is: Does the researcher place a value on the infrastructure and the normal farming operation, or does the researcher value the farming business in total?

Guidelines of the American Society of Farm Managers and Rural Appraisers Inc. indicate that the three known approaches, namely the cost, income-capitalised and salescomparison approaches should be used when valuing agricultural units (Cooley, 1998:43). Further assessment regarding the practical application of broiler units revealed that all three methods were used in the valuation of broiler units.

In an international study conducted by French (2004:536), it was found that valuation models in the UK can be grouped as follows:

- the comparable method;

- the investment/income method;

- the accounts/profit method;

- the development/residual method; and

- the contractor's/cost method.

In the USA and Germany, on the other hand, only three principal methods are used, namely:

- the capital-comparison method;

- the investment method; and

- the depreciated replacement-cost method.

A way in which it is possible to estimate the market value of land and property is the contractor's method or the replacement-cost method. If the property being valued is so specialised that properties of that nature are rarely sold on the open market, it would be effectively impossible to assess its value by referring to comparable sales of similar 
properties. Similarly, if there is no rental produced, the investment method would also be inappropriate. The profit method can be applied if the property is intrinsically linked to the business carried out on the property. However, where such business is one of production rather than service, it is difficult to determine the contribution of the property to the overall usage. Thus, once again, the valuer should revert to understanding the thought process of the user of the building. Here, the nature of the business is so specialised that there are no comparisons; thus the owner of the building would simply assess the market value of the building by referring to its replacement cost, that is, how much it would cost to replace the property if the business was deprived of its use. In simple terms, market value would equate to reconstruction costs. The valuer would assess the market value of the raw land (by referring to comparable land values in an appropriate alternative use), add the cost of re-erecting a building which could perform the function of the existing structure, and from this make subjective adjustments to allow for the obsolescence and depreciation of the existing building relative to the new hypothetical unit. It is reasonable to assume that this mirrors the thought process of the owner-occupier and should thus be viewed as a valid and rational method of valuation. This describes the contractor's or cost method (French, 2004:537).

The judge in the court case between Minister van Waterwese v Mostert 19664 SA 690 (A) 723F; Minister van Waterwese v Von During 19711 SA 858 (A) 971A; D Brown, Land Acquisition, 199 states the following:

It seems to be accepted that the decision as to which method should be used to determine the market value of comparable sales by the court, is generally prepared to rely on the judgment of the valuer as to which he uses.

The factors influencing the value of broiler units are sophisticated and, therefore, the researcher believes that any valuers who are justified or qualified to value broiler units should be well-informed and take all the factors into consideration when valuing a broiler unit.

According to the principles of old Roman and Roman-Dutch law, people should be well-informed and people are assumed to undertake businesses in which they have skill (National Property Education Committee, 2004:3).

The same literature (National Property Education Committee, 2004:4) refers to Bailment:

Nor will want of ability to perform the contract be any defence to the contracting party, for though the law exacts no impossible things, yet it may justly require that every man should know his own strength before he undertakes to do an act. And if he deludes another by false pretension to skill he should be responsible for any injury that may be occasioned by such delusion.

Thus the valuer has the choice of a number of methods. The method used would be a reflection of the available information in the market place, the knowledge and the experience of the valuer. Generally, the less information in the form of comparable sales, the more the valuer would be inclined to use a model that reflects the role of 
property as an asset to the business. Such properties tend to be referred to as specialised properties. Conversely, where there are a lot of comparable transactions (either in the form of capital value and/or rent values or statistics/yields), the valuer may value without reference to the original thought process of the occupier. The valuer may use "second-hand" information from comparable properties and interpret the information within the context of the current market to estimate the price of the subject property. This procedure can be used for non-specialised properties (French, 2004:538). French (2004:534) refers to a specialised property as a property where there is insufficient market data to value it by some form of comparison. The assumption with all valuations of specialised buildings is that they should be valued on the assumption that the existing use of the building would continue perpetually. Based on this assumption, improvement on agricultural land can result in specialised property. As such, the value is determined on an accounts or profit method (French, 2004:540).

The market for agricultural land differs from most other markets in that the supply is virtually fixed. Under such circumstances, it is often said that the price would be determined by demand alone. However, this is not a very accurate way of articulating it. The precise explanation for the situation would be that the price of the stock (the stock being unchangeable) would have to adjust itself to such a level that those who would inevitably have to keep this stock would, in fact, have to be comfortable in keeping it (Clark \& Litt, 1973:1). Clark and Litt (1973:1) also state that land has value because it can earn rent. The word rent has multiple meanings. In most cases, it represents payment for the use of buildings, roads, hedges, fences, drainage and other fixed improvements, as well as for the land itself. Rent is also the amount by which actually received proceeds exceed the minimum amount that would have been necessary to evoke the supply of the production factors required. In the case of agricultural land, the minimum amount required to evoke its services would be the provision for maintenance, depreciation and interest on buildings, and other fixed improvements.

\subsection{The valuation process}

The valuation process is systematic. First of all, the valuer must determine the use of the farm. Murray (1973:381) postulates that the highest and best use is another essential factor which presents difficulties, because the type of farming which is the highest and best use are not always being followed on a farm. Concurring with this, Scribner (1997:469) stresses that the appraisal contains many significant conclusions, of which two are major: the highest and best use, and the value. he first may be a complete study in itself; the second depends on the first. After determining the nature and the purpose of the appraisal, the valuer examines the property and its surroundings and assembles the relevant information concerning the various physical, economic and institutional factors that affect its value. This data is interpreted and one or more of the standard valuation approaches is used in computing the value of the property. Any differences that may result from the use of the alternative valuation technique should then be reconciled and a valuation report submitted that indicates the appraiser's opinion of the value of the property. A very important aspect is that the producer must have a growing contract; otherwise he or she will probably not have a market for his broilers. This contract is like the quota system for cane growers, as described by National Property Education Committee (2004:9). 
A poultry unit normally changes hands as a going concern. For example, sugar cane farms and other specialised agricultural properties change hands as a going concern, lock, stock and barrel (National Property Education Committee, 2004:12). Broiler units also change hands lock, stock and barrel. But if a price is too high, the investor would negotiate a contract with a commercial producer and develop its own broiler unit.

\section{$3 \quad$ Research Methodology}

Data was gathered by means of assessments of previous valuations as well as physical valuations done in the field. There are only a few valuers who specialise in the field of agriculture and even fewer in the field of broiler farms. Information on international and local valuers who specialise in broiler units was gathered via the Internet, the South African Institute of Valuers (SAIV) and South African financial institutions like commercial banks. Interviews with the different valuers were held to obtain the necessary information about and valuations of broiler units.

Three major approaches were identified for the valuation of broiler farms, namely the comparable, cost and capitalisation methods. These approaches are well known to the South African valuation industry. In general, a quantitative approach was followed with the accumulation, analysis and interpretation of the result.

Normally, valuers in South Africa do not apply more than one valuation method if the instructor does not request it. Quite a number of valuations investigated only had one method applied. To make the necessary comparison, application of more than one valuation method was required. The researcher was responsible for the additional valuations. Where only one valuation method was used, it was enhanced with further valuation applications. Valuations done only on the basis of the cost approach were enhanced by further economic data from the broiler producer to establish a value on the basis of the income-capitalised method. Valuations of farms done with the incomecapitalised method were enhanced with a cost approach.

The geographical area was limited to the Mpumalanga and North West provinces in South Africa. The size of the broiler houses was at least $1000 \mathrm{~m}^{2}$. Broiler units with a minimum of four houses were taken into account. A sample of 15 out of the 196 contract broiler farm valuations was selected.

Other activities influencing an agricultural property, like other improvements and other agricultural and business activities, were eliminated from the study. Only the necessary infrastructure for the production of broiler units was taken into account.

All the data received was converted to square meter $\left(\mathrm{m}^{2}\right)$. Raw data was organised and classified; statistical analysis was performed by the application of the PH Stats package in a Microsoft Excel Worksheet (Levine et al., 2005:46).

Figures were tested for normality; differences between the overall means were determined by the analysis of variance, using the ANalysis Of VAriance (ANOVA) test 
(Leedy \& Ormrod, 2001); the correlation coefficient between the two different methods and the dependable variable were determined; and regression analysis was fitted.

A multiple approach was necessary to achieve the research goals. Valuers registered as professional or associated valuers with the SAIV, and the Board of Valuers and Agricultural Advisors did assessed valuations.

All the information was obtained by means of interviews and inspections over the period 2005-2007. Technical aspects taken into account were:

- quantity of broiler houses;

- $\quad$ size of individual broiler houses;

- age of broiler houses;

- heating system;

- feeding system;

- ventilation system;

- watering system;

- lighting system;

- standby generator;

- electricity back-up;

- waste management; and

- bird health.

\section{Findings and Discussion}

The study evaluated the comparable sales of two properties; determined a capitalisation rate; tested the data for normality; fitted a multiple regression on the income-capitalised method's data; and investigated a correlation between the income-capitalised method and the cost approach.

Very limited data on comparable sales was available. Table 1 and 2 provides information regarding sales that meet the requirements of an open market transaction.

Property 1 was valued by a registered valuer from Absa Bank, using the cost-approach method. The property valued at R7.65 million. A professional associated valuer valued Property 2, also using the cost-approach method. The property was valued at R3.7 million.

Table 1 : Specifications on comparable sales

\begin{tabular}{|l|cc|}
\cline { 2 - 3 } \multicolumn{1}{c|}{} & Property 1 & Property 2 \\
\hline Farm Name & Modderfontein & Vaalrivierdrift \\
Registration Div. & IP & HS \\
Farm Number & 188 & 2 \\
Portion & 1 (remaining) & 6 \\
Province & North West & Mpumalanga \\
Extent & 338.338 ha & 131.624 ha
\end{tabular}




\begin{tabular}{|l|cc|} 
Local Authority & Ventersdorp Local Municipality & Lekwa Local Municipality \\
Title Deed Nr & T835/1995 & T59388/2003 \\
Owner 1 & Slabbert JF & Frikkie Lyons Familie \\
& ID No 480219 5015051 & Trust \\
Owner 2 & Slabbert AE & R4 800000 \\
Selling Price & ID No 540111 8006 084 & 6 Nov 2006 \\
Selling Date & R9 328 000 & \\
\hline
\end{tabular}

Table 2 : Technical aspects on a broiler unit for the calculation of value via the incomecapitalised method

\begin{tabular}{|l|cc|}
\cline { 2 - 3 } \multicolumn{1}{c|}{} & Property 1 & Property 2 \\
\hline Contract party & Astral Foods & Supreme Poultry \\
Quantity of houses & 4 & 4 \\
Surface $\left(\mathrm{m}^{2}\right)$ & 1728 & 1078 \\
Total surface $\left(\mathrm{m}^{2}\right)$ & 6912 & 4312 \\
Cost of DoC (Rand) & 2.50 & 2.50 \\
Chicks per house & 30000 & 21600 \\
Total chicks per cycle & 120000 & 86400 \\
Cycles per year & 7.3 & 7.2 \\
Mortality (percentage) & 7.5 & 6.5 \\
Total chicks delivered per cycle & 111000 & 80784 \\
Average rounded weight (kg) & 1.75 & 1.8 \\
Total average weight delivered (kg) & 194250 & 145411 \\
Average selling price (Rand) & 7.60 & 7.60 \\
FCR & 1.7 & 1.69 \\
Feed consume per bird (kg) & 2.975 & 3.042 \\
Average feed price (Rand) & 2500 & 2500 \\
Management fees (Rand) & 120000 & 120000 \\
Value of loose equipment (Rand) & 1516032 & 1261000 \\
Provision for capital replacement (Rand) & 151603 & 126100 \\
\hline
\end{tabular}

Table 3 summarises the valuations done by different valuers. The valuations were divided into the following components: 
Table 3 : Valuation results of properties as units

\begin{tabular}{|l|rrrr|}
\cline { 2 - 5 } \multicolumn{1}{c|}{} & \multicolumn{2}{c}{ Property 1 } & \multicolumn{2}{c|}{ Property 2 } \\
\cline { 2 - 5 } \multicolumn{1}{c|}{} & \multicolumn{1}{c}{ Value } & Percentage & \multicolumn{1}{c|}{ Value } & Percentage \\
\hline Land & R1 353 617 & $17.69 \%$ & R294 936 & $7.96 \%$ \\
Improvements & R666 258 & $8.71 \%$ & R373 064 & $10.07 \%$ \\
Broiler unit & R5 630 976 & $73.61 \%$ & R3 038 499 & $81.98 \%$ \\
Value (rounded) & R7 650 000 & & R3 706 499 & \\
\hline
\end{tabular}

The methodologies used in the depreciated value for broiler house by the specific valuers are as follows:

- Broiler houses (standard - semi-environmental control) with a concrete floor, electricity and drop sides (Early Bird type) are valued at R 950/m2 less depreciation for condition. (Approximately 30-50\% of the price of the "house" is made up of movable assets, which do not form part of the valuation) (17-21 broilers $/ \mathrm{m} 2)$.

- Broiler houses (sophisticated - fully environmental control) with a concrete floor, electricity, drop sides (Early Bird type): R 1 100/m2 less depreciation for condition. (Approximately 30-50\% of the price of the "house" is made up of movable assets, which do not form part of the valuation) (17-21 broilers $/ \mathrm{m} 2)$.

The depreciated valuation of the broiler units is illustrated in Table 4.

Table 4 : Valuation of broiler units (Depreciated-cost approach)

\begin{tabular}{|lll|}
\cline { 2 - 3 } \multicolumn{1}{c|}{} & \multicolumn{1}{c|}{ Sale 1 } & \multicolumn{1}{c|}{ Sale 2 } \\
\hline Depreciated value of loose equipment & R1 516 032 & R1 261 000 \\
Depreciated value of fix improvement & R4 114 944 & R1 777 499 \\
Depreciated value (cost approach) & R5 630 976 & R3 038 499 \\
Depreciated value $/ \mathbf{m}^{2}$ & R $\mathbf{8 1 5}$ & R \\
\hline
\end{tabular}

Property 1 was sold for R9.33 million and Property 2 for R4.79 million. If a weighted average principle is applied to the above valuations, the valuations can be adjusted accordingly (Table 5).

Table 5 : Adjusted valuations of the broiler units

\begin{tabular}{|l|cc|}
\cline { 2 - 3 } \multicolumn{1}{c|}{} & \multicolumn{1}{c|}{ Sale 1 } & Sale 2 \\
\hline Land value & R 1650882 & R 381 153 \\
Value of improvements & R 812573 & R 482 120 \\
Value of broiler unit & R 6867582 & R 3 926 727 \\
Value (rounded) & R 9 330 000 & R 4 790 000 \\
\hline
\end{tabular}

A capitalisation rate is market-determined by the in-depth analysis of the sales of similar properties (cf. Cloete 2004:33).

If a market value of R6.87 million is used on the broiler part of the valuation for Property 1, as calculated in Table 5, with a net margin of R1.17 million per year, as 
calculated from specifications illustrated in Table 2, the discount rate is calculated at $17.05 \%$ for this comparable sale.

If a market value of R3.25 million is used on the broiler part of the valuation of the comparable sale (Property 2), as calculated in Table 1, with a net margin of R700 000 per year, as calculated from specifications illustrated in Table 2, the discount rate is calculated at $17.9 \%$ for this comparable sale.

\subsection{Statistical Analysis}

\subsubsection{Descriptive statistical output}

The sample size ( 15 out of a population of 196 ) represents $7,65 \%$ of the population. The small sample size can be seen as a limitation; however, the uniform spread of data should be borne in mind. Data is converted to rand $/ \mathrm{m}^{2}$. Two sets of data are used: the one set of data represents the value derived from the depreciated cost approach of the 15 broiler units, while the other set of data represents the value derived from the incomecapitalised method for the same 15 broiler units. A test for normality was done and the mean standard deviation and coefficient of variation were calculated. The correlations between variables and between the values derived from the different valuation methods were also tested. Multiple regression statistics were applied.

\subsubsection{Test for normality}

For many population distributions with small to moderate-sized datasets, a dot scale and a box-and-whisker plot should be constructed to test for normality (Levine et al., 2005:241). Both of these were prepared.

\subsubsection{Box and whiskers diagram}

Figure 1 below illustrates a box and whiskers plot for the value derived from the income-capitalised method $\left(\mathrm{R} / \mathrm{m}^{2}\right)$.

As illustrated in Figure 1, the data is a little bit skewed to the right, indicating a positive distribution. There is a longer tail to the right of the distribution and a distortion that is caused by larger or higher values - these values pull the mean upwards so that it is greater than the median (Levine et al., 2005:120). The researcher is of the opinion that the data is fairly normally distributed. The reason for the skewness could be good management, irrespective of the age of a house. This method does not isolate the effect of management. 


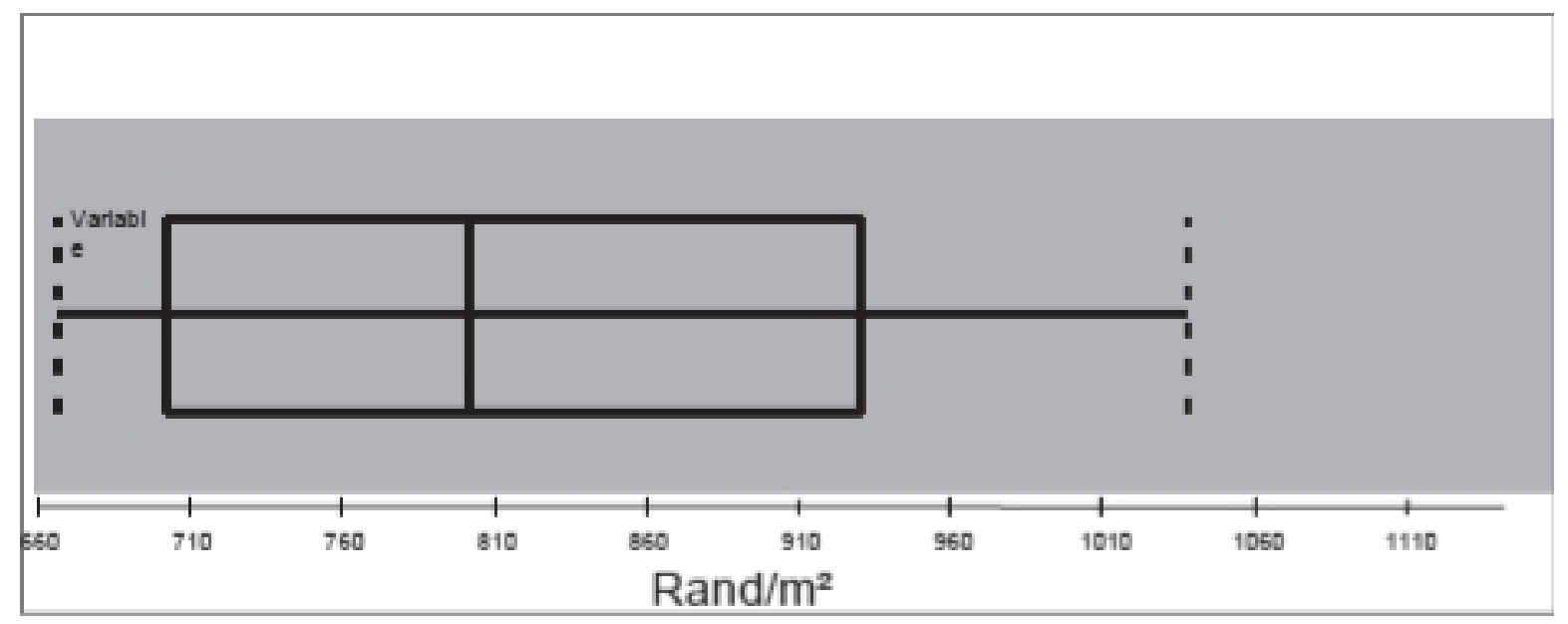

Figure 1 : Income-capitalised value $\left(\mathrm{R} / \mathrm{m}^{2}\right)$ (Box and whiskers plot)

Figure 2 illustrates the box and whisker plot for value derived from the cost method $\left(\mathrm{R} / \mathrm{m}^{2}\right)$.

The data is skewed to the left, indicating a negative distribution. The result shows that the mean is smaller than the median (Levine et al., 2005:120). Negative skewness arises when the mean is decreased by low values.

The result could be due to older broiler houses, where movable assets have already depreciated in value.

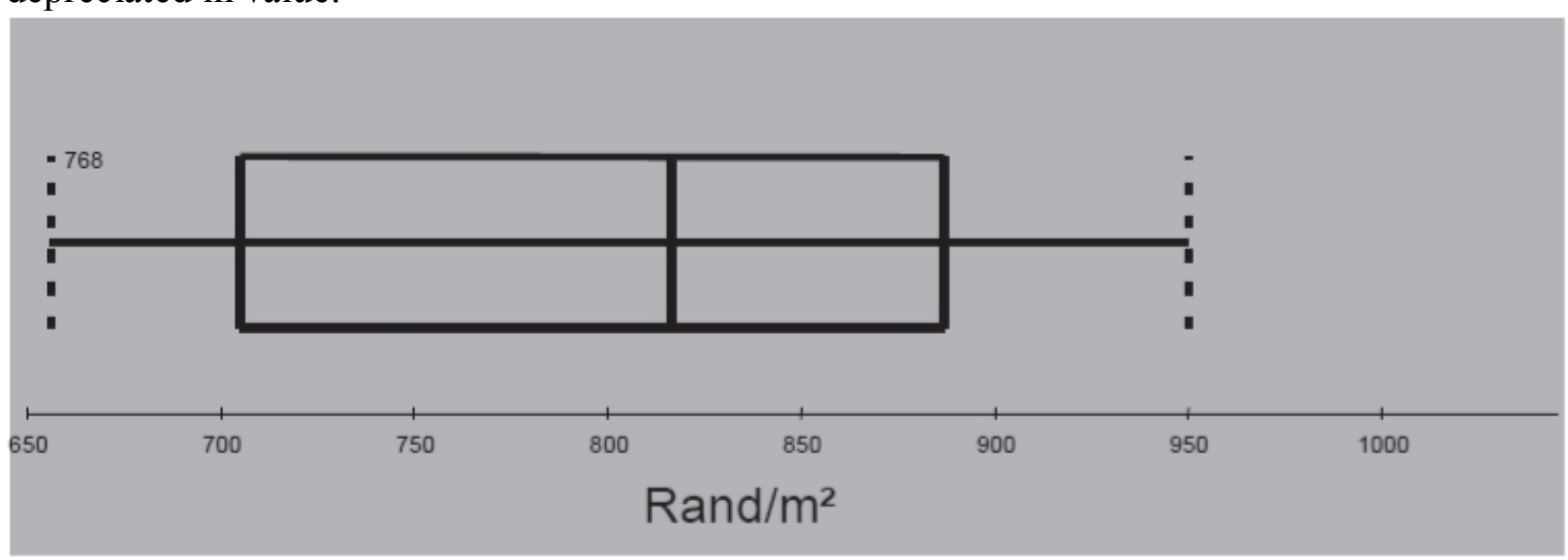

Figure 2 : Value from cost method $\left(\mathrm{R} / \mathrm{m}^{2}\right)$ (Box and whisker plot)

\subsubsection{Dot scale diagram}

Table 6 : Statistical calculated data (Income-capitalised and depreciated-cost approach)

\begin{tabular}{|c|c|c|}
\hline & Income-capitalised values & $\begin{array}{l}\text { Depreciated-cost } \\
\text { values }\end{array}$ \\
\hline Mean & 817.31 & 805.47 \\
\hline Median & 802.17 & 815 \\
\hline 1st Quartile & 702.20 & 705 \\
\hline 3rd Quartile & 930.80 & 887 \\
\hline
\end{tabular}


The mean and median are the balancing points of distribution which, in this case, show a relatively normal distribution of data.

The dot scale diagram reflects the distribution of the data with the values, mean, median standard deviations and quartiles, as illustrated in Figures 3 and 4.

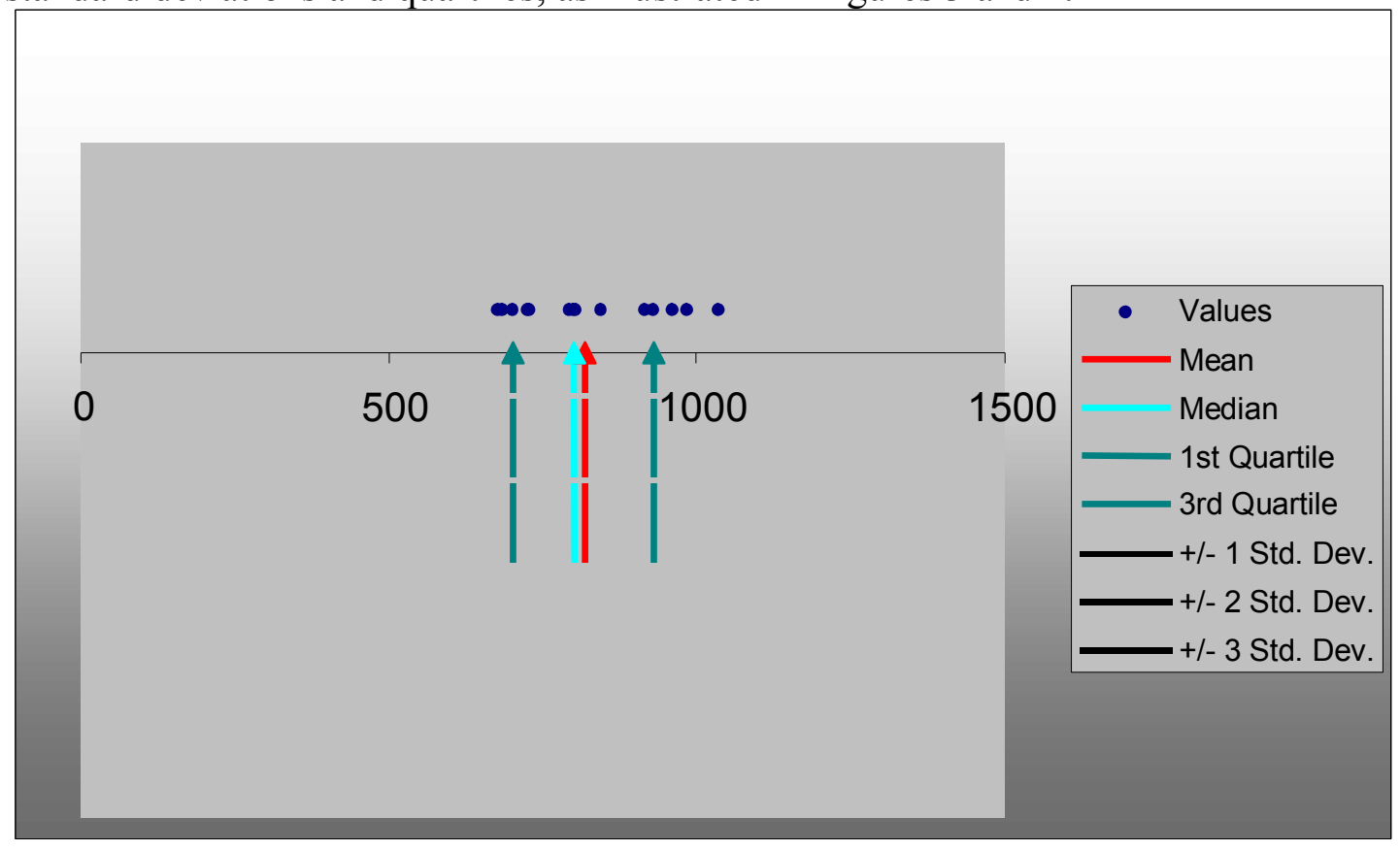

Figure 3 : Income-capitalised value $\left(\mathrm{R} / \mathrm{m}^{2}\right)$ (Dot scale plot)

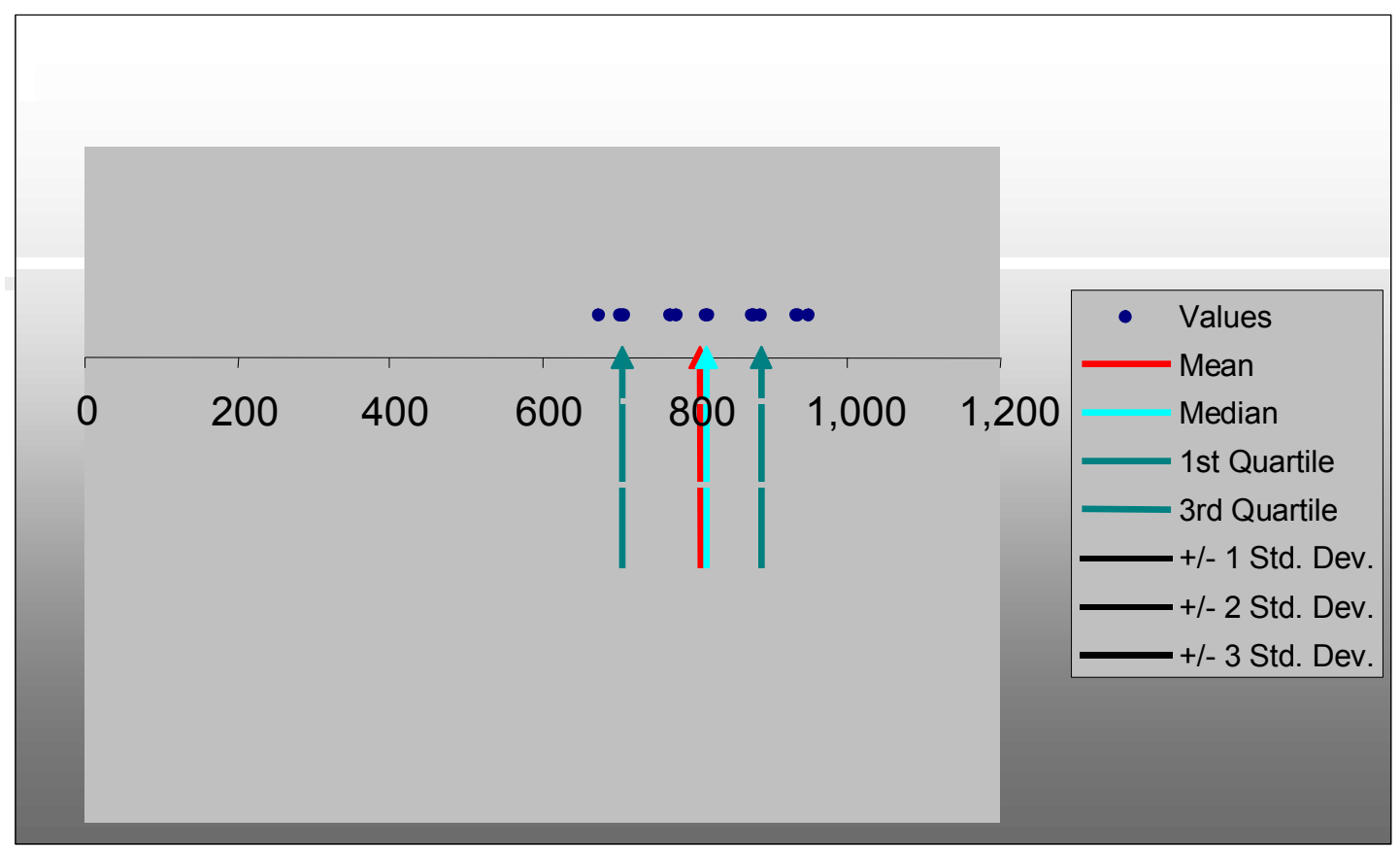

Figure 4 : Value derived from cost approach $\left(\mathrm{R} / \mathrm{m}^{2}\right)$ (Dot scale plot) 
The standard deviation is the squared root of the variance of a statistic, which in this cas is the percentage of the values derived at per square meter. Calculation of the standard deviation indicates that the sample broiler units are clustered within $\mathrm{R} 122.92 / \mathrm{m}^{2}$ around the mean of $\mathrm{R} 817.31 / \mathrm{m}^{2}$, using the income-capitalised method (i.e., clustering between $X-1 S=694.39$ and $X+1 S=940$ ). In fact, $60 \%$ of the data for the income-capitalised method lies within the interval. For the calculated depreciated value derived from the cost approach, the mean is calculated to be R805.47 and a standard deviation of $\mathrm{R} 100.87 / \mathrm{m}^{2}$, once again indicating that $60 \%$ (9 of 15 observations) lies within the interval.

The coefficient of variation $(\mathrm{CV})$ is a relative measure of variation. It is always expressed as a percentage rather than in terms of units of the particular data. The CV measures the scatter in the data relative to the mean. In the analysed data, the observation is made that the values derived from the income-capitalised method scattered more around the mean $(15.04 \%)$, than the values derived from the depreciatedcost approach $(12.52 \%)$. The reason for the above is that the basis of the calculation for the cost approach relies on depreciation and a norm for replacement cost, while the basis of calculation for the values derived from the income-capitalised method arises from the net margin.

\subsection{Multiple Regression Fit on the Income-Capitalised Value}

When a valuer determines a value, he/she should consider the most suitable points of contriving. The value is supposed to be the most probable point of value, therefore statistics and statistical application play a major role in valuation techniques (Steyn, 2003:57).

Lizieri and Venmore-Rowland (1991:121) are also of the opinion that a valuation does not have a definite point, but rather a lot of points contriving to the value. There is no guarantee that the determined points would form the balance of an interval or that the distribution is normal.

Many people question the integrity of valuation (Lizieri \& Venmore-Rowland, 1991:115). Waller (in Steyn, 2003:59) describes traditional methods as subjective and time-consuming. It is therefore necessary to use statistics to give valuations more credibility (cf. Detwiler \& Radigan, quoted in Steyn, 2003:60). It must be borne in mind that a lack of statistical knowledge, time constraints and insufficient data can hinder the application of statistical analysis.

\subsubsection{Variables taken into account}

The following variables were taken into account for the determination of value $/ \mathrm{m}^{2}$ :

- $\quad Y i \quad: \quad$ Income-capitalised value $/ \mathrm{m}^{2}$

- $X_{1}:$ Average slaughter weight $(\mathrm{kg})$

- $X_{2}:$ Net margin $/$ year $/ \mathrm{m}^{2}$

- $X_{3}:$ FCR 
- $X_{4} \quad: \quad$ Broilers $/ \mathrm{m}^{2}$

- $X_{5}:$ Cycles per year

- $X_{6}:$ Mortality

- $X_{7} \quad: \quad$ Total size of house in $\mathrm{m}^{2}$

- $X_{8} \quad: \quad$ Cycle in days

\subsubsection{ANOVA table and adjustment}

Table 6 illustrates an ANOVA table of multiple regression.

The model can be fitted as follows:

$Y i=\beta_{0}+\beta_{1} X_{1 i}+\beta_{2} X_{2 i}+\beta_{3} X_{3 i}+\beta_{4} X_{4 i}+\beta_{5} X_{5 i}+\beta_{6} X_{6 i}+\beta_{7} X_{7 i}+\beta_{8} X_{8 i}+\varepsilon_{i}$

Income-capitalised value $/ \mathrm{m}^{2}=$

$$
\begin{aligned}
& -264.2227+1236.3129 X_{1 i^{+}}+7.2711 X_{2 i}{ }^{-} \\
& 664.8548 X_{3 i}-7.4621 X_{4 i}+10.8874 X_{5 i}+ \\
& 3706.5383 X_{6 i}+0.0057 X_{7 i}+-34.6437 X_{8 i}+\varepsilon_{i}
\end{aligned}
$$

\subsubsection{Coefficient of multiple determination}

The $\mathrm{R}$ Square measures the portion in variation in $\mathrm{Y}$ that is described by the set of explanatory variables selected.

The coefficient captured is 0.9481 . This means that $94.81 \%$ of the variation in value per square meter, determined via the income-capitalised method, can be explained by the

\begin{tabular}{|c|c|c|c|c|c|c|}
\hline \multicolumn{2}{|c|}{ Regression Statistics } & & & & & \\
\hline Multiple R & 0.97373 & & & & & \\
\hline R Square & 0.94815 & & & & & \\
\hline Adjusted R Square & 0.71235 & & & & & \\
\hline Standard Error & 59.58254 & & & & & \\
\hline Observations & 15 & & & & & \\
\hline \multicolumn{7}{|l|}{ ANOVA } \\
\hline & $D f$ & $S S$ & $M S$ & $F$ & \multicolumn{2}{|c|}{ Signif $F$} \\
\hline Regression & 9 & 389496.03 & 43277.34 & \multirow{3}{*}{13.714} & \multirow{3}{*}{\multicolumn{2}{|c|}{0.005}} \\
\hline Residual & 6 & 21300.48 & 3550.079 & & & \\
\hline \multirow[t]{2}{*}{ Total } & 15 & 410796.51 & & & & \\
\hline & Coefficients & $\begin{array}{l}\text { Standard } \\
\text { Error }\end{array}$ & t Stat & p-value & Lower 95\% & $\begin{array}{l}\text { Upper } \\
95 \%\end{array}$ \\
\hline Intercept & -264.2227 & 1141.6852 & -0.2314 & 0.8247 & -3057.83 & 2529.38 \\
\hline $\begin{array}{l}\text { Average slaughter } \\
\text { weight }(\mathrm{kg})\end{array}$ & 1236.3129 & 475.8197 & 2.5983 & 0.0408 & 72.02 & 2400.6 \\
\hline
\end{tabular}
variation of the variable.

Table 7 : Results of multiple regression on income-capitalised value $\left(\mathrm{R} / \mathrm{m}^{2}\right)$ 


\begin{tabular}{|lrrrrrr|} 
Net margin $/$ year $/ \mathrm{m}^{2}$ & 7.2711 & 0.9968 & 7.2945 & 0.0003 & 4.83 & 9.71 \\
FCR & -664.8548 & 368.9411 & -1.8021 & 0.1216 & -1567.62 & 237.91 \\
Broilers $/ \mathrm{m}^{2}$ & -7.4621 & 9.5039 & -0.7852 & 0.4622 & -30.72 & 15.79 \\
Cycles per year & 10.8874 & 41.2544 & 0.2639 & 0.8007 & -90.06 & 111.83 \\
Mortality & 3706.5383 & 2111.0173 & 1.7558 & 0.1296 & -1458.94 & 8872.01 \\
Total size & 0.0057 & 0.0026 & 2.1648 & 0.0736 & 0 & 0.01 \\
Cycle in days & -34.6437 & 15.2678 & -2.2691 & 0.0637 & -72.00 & 2.72 \\
\hline
\end{tabular}

Some statisticians suggest that the adjusted R Square should compute to reflect both the number of explanatory variables in the model and the sample size. This is especially necessary when comparing two or more regression models that predict the same dependant variable but have a different number of explanatory variables. The results define the R Square as 0.7123 . Hence, $71.23 \%$ of the variation in value per square can be explained by the multiple regression.

\subsubsection{Residual analysis for the multiple regression model}

The first residual plot examines the pattern of residuals versus the predicted value of $Y$. It is clearly evident that the residuals are scattered, except for the residual plot of the capitalisation rate. This could be due to the discount rate being held consistently at $17.5 \%$.

This plot also provides evidence of a possible quadratic effect in at least one explanatory variable, a possible violation of the assumption of equal variance and/or a need to transform the Y variable (see Appendix 2). No evidence of homoscedasticity was found.

Plots were also used to investigate patterns in the residuals in order to validate the independence assumption when data is collected in time order. Associated with this are the Durban-Watson statistics and a positive autocorrelation indication among the residuals. Time series data was not used; therefore, no autocorrelation between the residuals could be investigated.

\subsubsection{Testing for significance of the regression model}

The test is required if there is a significant relationship between the dependant variable and the set of explanatory variables. Because there is more than one explanatory variable, the null and alternative hypotheses are explained as follows:

$H_{0}: \beta_{1}=\beta_{2}=\beta_{3}=\beta_{\mathrm{k}}=0 \quad$ (no linear relationship between the dependant variable and the explanatory variable)

$H_{1}$ : At least one $\beta_{\mathrm{j}} \neq 0 \quad$ (linear relationship between the dependant variable and the explanatory variable)

The null hypothesis is tested with the $\boldsymbol{F}$ test. If a 0.05 level of significance is used, the critical value of the $\mathrm{F}$ distribution is 8 , and 6 degrees of freedom obtained from any statistical table (critical value of F) is approximately 4.1. From Table 7 the F statistics given in the ANOVA table is 13.71. Because 13.71 $>4.1$, or because the p-value $=0<$ 
0.005, the researcher rejected $\boldsymbol{H}_{\mathbf{0}}$ and concluded that at least one of the explanatory variables is related to the income-capitalised value per square meter.

It would be necessary to test the contribution of each interaction separately in order to determine which interaction terms should be included in the model.

\subsubsection{Inferences concerning the population regression coefficient}

If a level of significance of 0.05 is selected, the critical value for $t$, for 6 degrees of freedom, should be between -2.4469 and +2.4469 . From Table 7 the $t$-value for the average slaughter weight $(\mathrm{kg})$ is 2.5983 and the net margin $/$ year $/ \mathrm{m}^{2}$ is greater than 2.4469 , therefore, we can reject the null hypothesis and conclude that there is a significant relationship between average slaughtered weight and the income-capitalised value. There is also a significant relationship between margins per square meter and the income-capitalised value per square meter. The $p$-value of both the variables above confirm the conclusion.

If we focus on the $p$-value of both the variables above, the conclusion is confirmed.

\subsection{Correlation Between Income-Capitalised Values And Depreciated-Cost Approach}

Table 8 illustrates the correlation between the income-capitalised value and the value derived from the depreciated-cost approach. The correlation for the 15 observations is $97.33 \%$.

Table 8 : Correlation between the income-capitalised value $\left(\mathrm{R} / \mathrm{m}^{2}\right)$ and the depreciated value-cost approach $\left(\mathrm{R} / \mathrm{m}^{2}\right)$

\begin{tabular}{|l|cc|}
\cline { 2 - 3 } \multicolumn{1}{c|}{} & $\begin{array}{c}\text { Income capitalisation } \\
\left(\mathbf{R} / \mathbf{m}^{2}\right)\end{array}$ & $\begin{array}{c}\text { Depreciated value } \\
\left(\mathbf{R} / \mathbf{m}^{2}\right)\end{array}$ \\
\hline $\begin{array}{l}\text { Income-capitalised value per square } \\
\text { metre }\end{array}$ & 1 & \\
Depreciated value per square meter & 0.973285062 & 1 \\
\hline
\end{tabular}




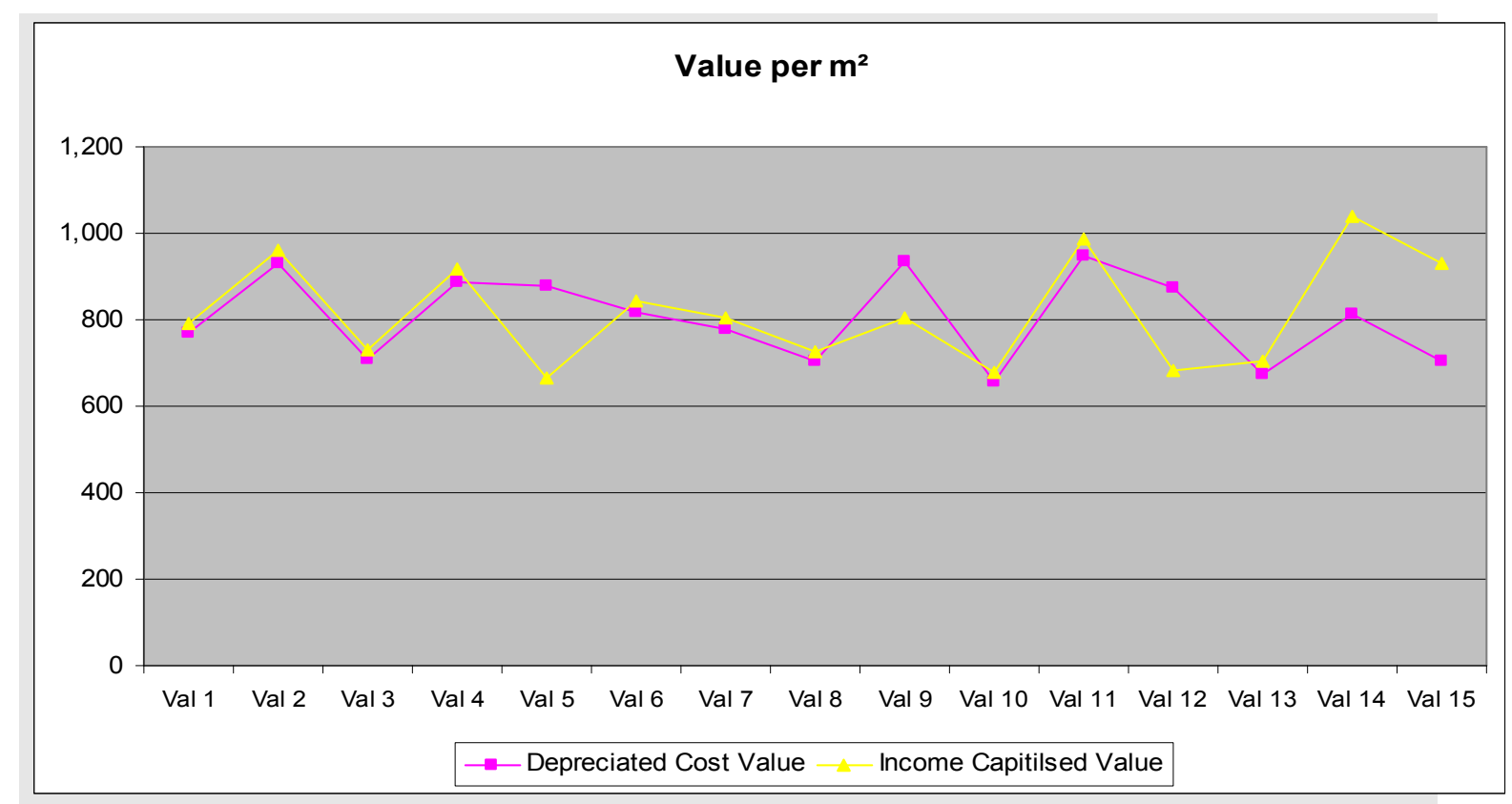

Figure 5 : Comparison between the values of the broiler houses under research

Good correlation existed between the cost and income-capitalised method. On the other hand, differences were detected between the two methods applied in some houses as illustrated in Figure 5.

Figure 5 illustrates the differences in some of the valuations and the importance for a multiple approach when valuing a broiler unit.

\section{Conclusion and Recommendations}

Although values derived from the two valuation methods differed in some cases, in most cases a strong correlation existed between the cost and income-capitalised methods.

Different emphases in the application of valuation methodologies were detected between the different financial institutions and valuers.

When the income-capitalised method is used, knowledge about the technical aspects like mortality, productive efficiency factor (PEF), feed cost ratio (FCR), price of day old chicks (DoC), price of feed, price of the live mass received and other cost and income components are crucial details in the valuation of a broiler unit.

When a valuer decides to use the cost approach, he/she should be fully aware of the cost concluded in such a valuation and should see every house as part of the total valuation. To determine the cost of erecting a broiler farm, the valuer needs knowledge on the before-and-after method, the land/surface preparation, the steel structure, bricks and mortar, heating, the waste system, watering and feeding systems, electricity and control systems, support systems when shortage of water is experienced, backup systems for power failures and so on. 
Alternative methods, like multiple regression analysis, can be used and seen as add-ons if the valuer has enough data.

The differences in the coefficient of variance between the two sets of data used indicates that the cost approach results in a smaller variation around the mean. The income-capitalisation indicates a more realistic approach, however, because it is based upon the net income and not on costs of replacement and allowances for depreciation.

Given the importance of the broiler industry, it is important for South Africa to do the necessary research on the first and secondary effect of factors influencing the value of the industry. Possible topics for further research include:

- What is the influence of government policies on the South African poultry industry?

- How competitive is the South African poultry industry with other countries?

- Why is there a difference between the income-capitalised approach and the depreciated-cost approach?

- How applicable is the above methodology towards other specialised agricultural units like laying houses, DoC production, piggeries, wineries, etc.?

- What is the influence of management on the value of a broiler house?

\section{Acknowledgements}

- Dr Jan Herholdt for the time, his expert guidance, patience, constructive ideas and encouragement.

- The Commercial Valuation Department of Absa, especially Jaco Goosen, Marius Nel, Piet Smith and Gert Botha.

- The Agricultural Division of Standard Bank and their Agricultural Team, especially Gerrit Maritz and Bertie Smith.

- Christo Claasens from Landbank Lichtenburg for providing information regarding the financing of broiler units by Landbank.

- Johann Reyneke from Tetragon Valuers (Pty) Ltd for providing valuable information.

- Mark A Lewis, appraiser from Dickerson-Seely \& Associates Inc, Lufkin, Texas, for supplying valuations used in America.

- Broiler farmers in South Africa who participated in the research.

- Mr Z de Beer, editor of the South African Poultry Bulletin, for information provided.

\section{References}

Behrmann, H.I. (ed.) 1995. Farm Land Valuation. Department of Agricultural Economics, University of Natal, Pietermaritzburg.

Clark, C. and Litt, D. 1973. The value of agricultural land. Canada: Pergamon Press.

Cloete, C.E. (ed.) 2004. Property valuation for expropriation and special purposes. SA Property Education Trust, Sandton, South Africa. 
Coetzee, L. \& Steyn, M. 2004. An approach to calculate the productive value of farmland. The South African Valuer. No 80, December 2004.

Cooley, M.A.L 1998. Complete Appraisal - Self contained report: Wigley Broiler farm F.M. Highway 698 Central Height Community Nacogdoches County, Texas 75669.

French, N. 2004. Practice Briefing: The valuation of specialised property: A review of valuation methods. Journal of Property Investment and Finance, 22(6):533.

Green, J.E.P. 1995. Chapter 4, Valuation of farm buildings (pp32 -34). in Farm Land Valuation. Edited by Behrmann. Published by the Department of Agricultural Economics, University of Natal, Pietermaritzburg.

Griffiths, D. 2005. Workschool session on farm valuation. Paper. Practical workschool: The South African Institute of Valuers. 2-6 May 2005.

Herholdt, J.A. 2004. Assessment of small-scale sugar farms in Mpumalanga. Unpublished treatise in Master of Science (Real estate), University of Pretoria.

Leedy, P.D. \& Ormrod, J.E. 2001 Practical research: planning and design. ( $7^{\text {th }}$ ed.) Upper Saddle River, N.J., Merrill Prentice Hall.

Levine, D.M., Stephan, D., Krehbiel, T.C. \& Berenson, M.L. 2005. Statistics for Managers. $\left(4^{\text {th }}\right.$ ed.) Upper Saddle River, New Jersey: Pearson Education, Inc.

Lizieri, C. \& Venmore-Rowland, P. 1991. Valuation accuracy: a contribute debate. Journal of Property Research, 8:115-122.

Murray, W.G. 1973. Farm appraisal and valuation. ( $5^{\text {th }}$ ed.) lowa State publishers.

National Agricultural Marketing Council (NAMC) and Commark Trust. 2007. Subsector Study: Chicken Meat. Report No 2007-03.

Ratcliff, J. 2001. Current issues and likely challenges beyond 2005. Proceedings of the Second International Broiler Nutritionist's Conference, pp7-16. Rotoru, New Zealand.

Rothwell, G. 2001. World broiler industry overview. Proceedings of the Second International Broiler Nutritionist's Conference, pp1-6. Rotoru, New Zealand.

SAPA, 2006. Poultry industry profile. South African Poultry Association Unpublished report, March 2006.

SAPA, 2007. Poultry industry profile. South African Poultry Association Unpublished report, June 2007.

Steyn, M.M. 2003. Mass valuation of agricultural land for the introduction of Land Tax. Treatise submitted in partial fulfilment of the requirements for the degree MSc (Real Estate), Department of Construction Economics, University of Pretoria.

Suter, R.C. 1981. The appraisal of farm real estate. Department of Agricultural Economics Purdue University. Illinois, Danville, The Interstate Printers \& Publishers, Inc. 


\section{APPENDIX 1}

Example of the calculation of the income capitalised value of a broiler unit

\begin{tabular}{|c|c|c|c|c|}
\hline Number of houses & & 4 & & \\
\hline Size of houses & $\begin{array}{l}\text { Square } \\
\text { metre }\end{array}$ & 1078 & & \\
\hline Total size & $\begin{array}{l}\text { Square } \\
\text { metre }\end{array}$ & 4312 & & \\
\hline Cost of DoC & & R 2.50 & & \\
\hline $\begin{array}{l}\text { Number of chickens per house } \\
\text { per cycle }\end{array}$ & & 21600 & & \\
\hline $\begin{array}{l}\text { Number of chickens placed per } \\
\text { cycle }\end{array}$ & & 86400 & & \\
\hline Number of cycles per year & & 7.20 & & \\
\hline Mortality & & $6.50 \%$ & & \\
\hline Number of chickens sold per cycle & $93.50 \%$ & 80784 & & \\
\hline Average weight when rounded off & $\mathrm{kg}$ & 1.8 & & \\
\hline Total live weight sold & $\mathrm{kg}$ & 145411 & & \\
\hline Average selling price & $\mathrm{R} / \mathrm{kg}$ & R 7.60 & & \\
\hline Feed conversion rate (FCR) & & 1.69 & & \\
\hline Feed used per broiler sold & $\mathrm{kg}$ & 3.042 & $\mathrm{DOC}=40 \mathrm{~g}$ & \\
\hline Average feed price & $\mathrm{R} /$ ton & R 2500 & & \\
\hline Interest rate & & $13.00 \%$ & & \\
\hline Owners remuneration & Rand/year & R 120000 & & \\
\hline Value of loose equipment & Rand & R 1261000 & & \\
\hline Provision for capital replacement & & R 126100 & & \\
\hline Discounted at & & $17.50 \%$ & & \\
\hline ITEM & Per cycle & Per month & Peryear & Per chicken \\
\hline Income & R 1130325 & R 678195 & R 8138341 & R 13.99 \\
\hline Sales & R 1105125 & R 663075 & R 7956901 & R 13.68 \\
\hline Manure sold & R 25200 & R 15120 & R 181440 & R 0.31 \\
\hline Cost & R 1032773 & R 619664 & R 7435962 & R 12.67 \\
\hline Feed & R 657072 & R 394243 & R 4730918 & R 8.13 \\
\hline
\end{tabular}




\begin{tabular}{|c|c|c|c|c|}
\hline ITEM & Per cycle & Per month & Per year & Per chicken \\
\hline DoC & R 216000 & R 129600 & R 1555200 & R 2.67 \\
\hline Medicine & R 16667 & R 10000 & R 120000 & R 0.21 \\
\hline Heating & R 13333 & R 8000 & R 96000 & R 0.15 \\
\hline Electricity & R 13333 & R 8000 & R 96000 & R 0.15 \\
\hline Transport & R 8333 & R 5000 & R 60000 & R 0.10 \\
\hline Cleaning & R 10000 & R 6000 & R 72000 & R 0.12 \\
\hline Bedding & R 5000 & R 3000 & R 36000 & R 0.06 \\
\hline Labour & R 20000 & R 12000 & R 144000 & R 0.23 \\
\hline Repair and maintenance & R 20000 & R 12000 & R 144000 & R 0.23 \\
\hline Insurance & R 8333 & R 5000 & R 60000 & $\mathrm{R} 0.10$ \\
\hline Catching & R 10000 & R 6000 & R 72000 & R 0.12 \\
\hline Subtotal & R 998072 & R 598843 & R 7186118 & R 12.27 \\
\hline Interest on working capital & R 520 & R 312 & R 3744 & R 0.01 \\
\hline Provision for capital replacement & R 17514 & R 10508 & R 126100 & R 0.20 \\
\hline Management fees & R 16667 & R 10000 & R 120000 & R 0.19 \\
\hline Margin & R 97553 & R 58532 & R 702378 & R 1.32 \\
\hline INCOME CAPITALISED VALUE & & & R 4013591 & \\
\hline
\end{tabular}


APPENDIX 2

\section{Residual plots}

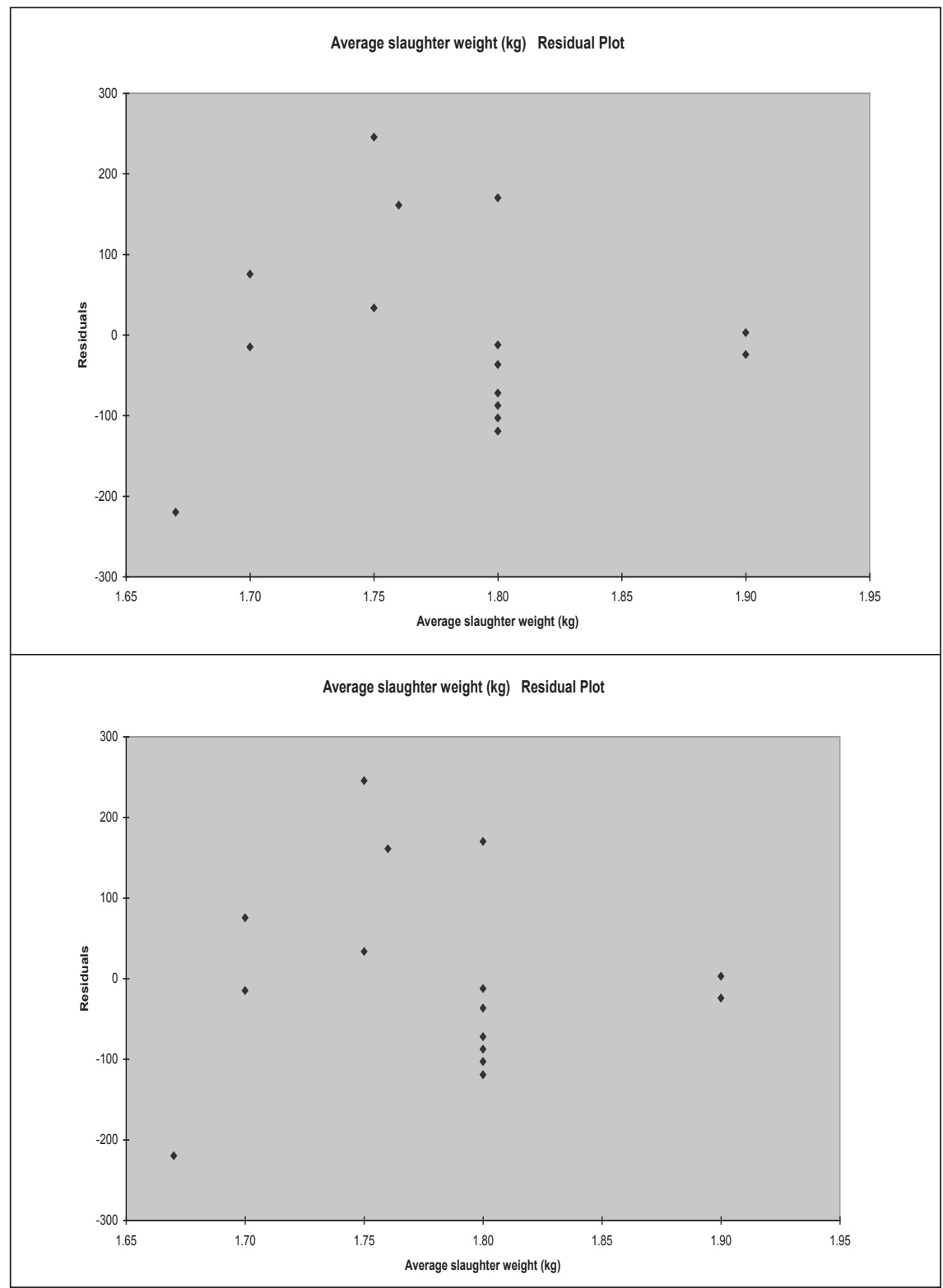


Feed conversion rate (FCR) Residual Plot

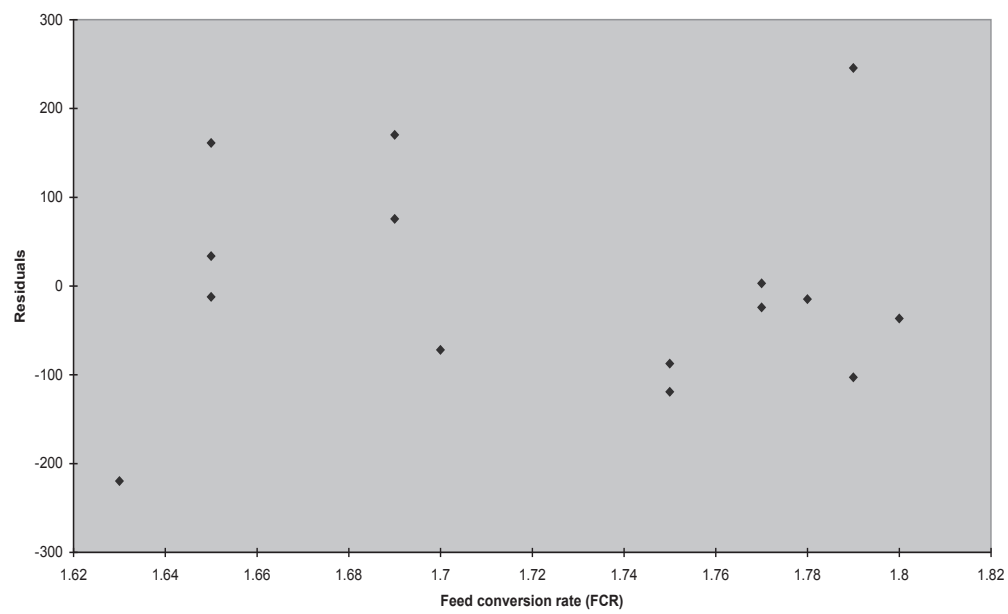

Broilers $/ \mathrm{m}^{2}$ Residual Plot

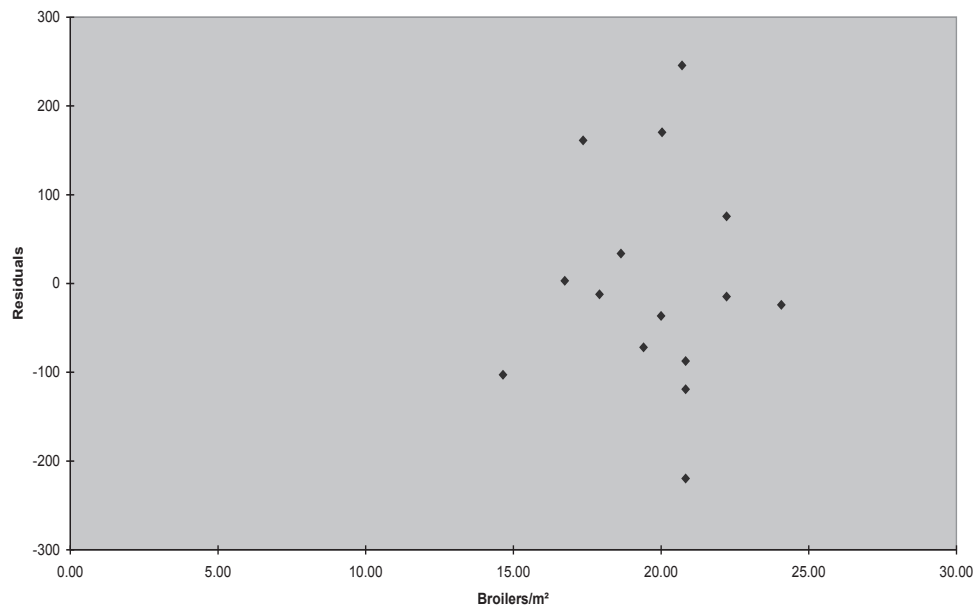




\section{Cycles per year Residual Plot}

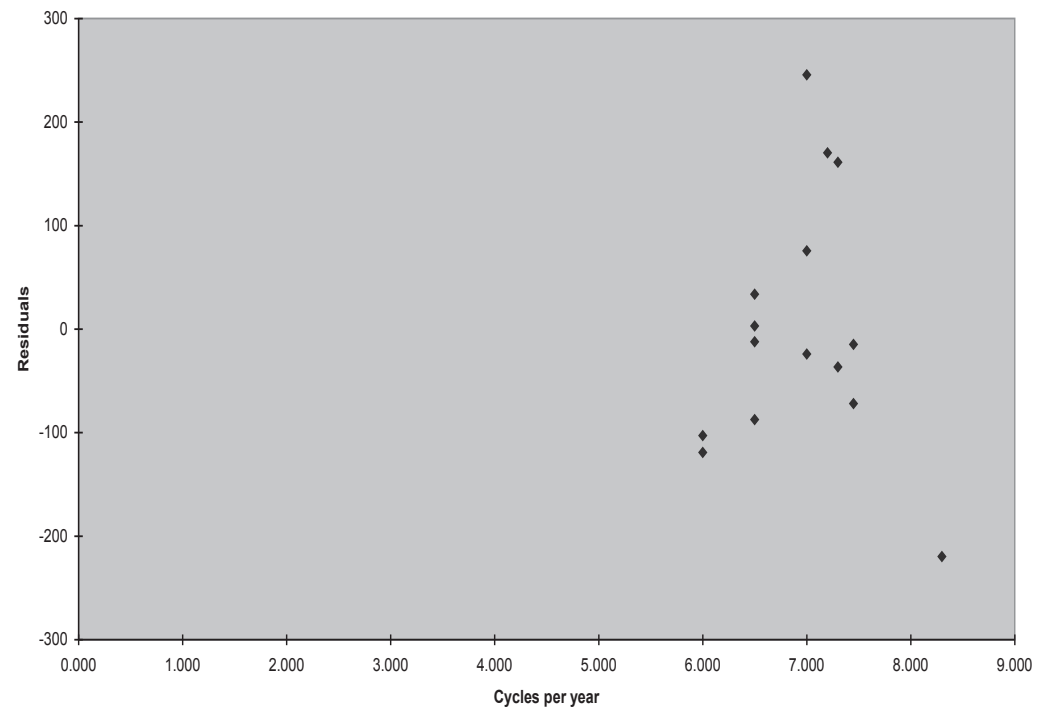

Mortality Residual Plot

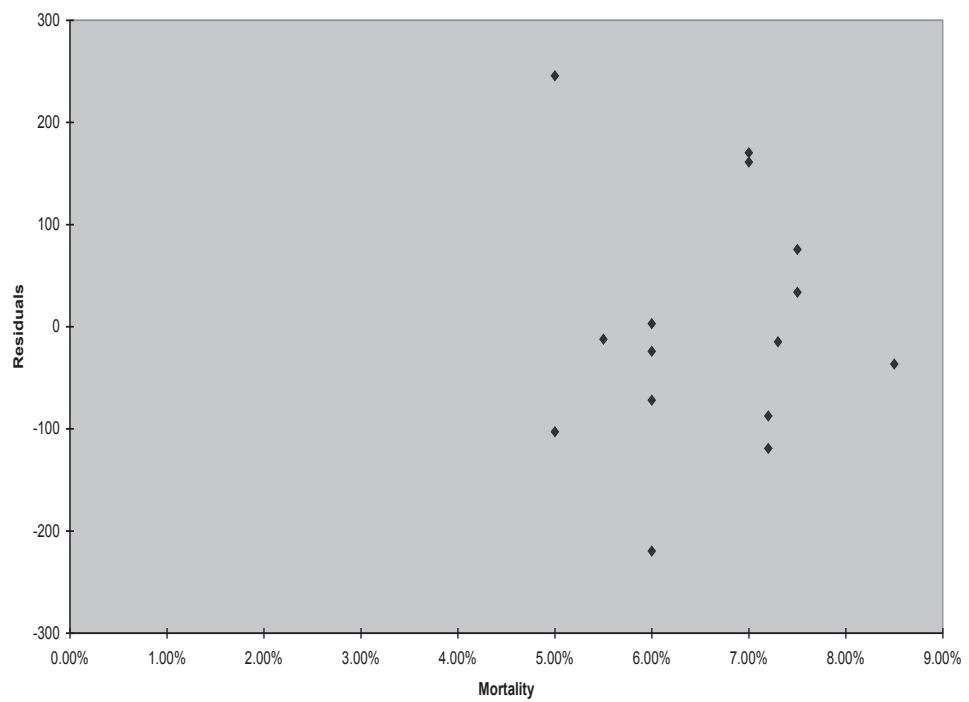


Total size Residual Plot

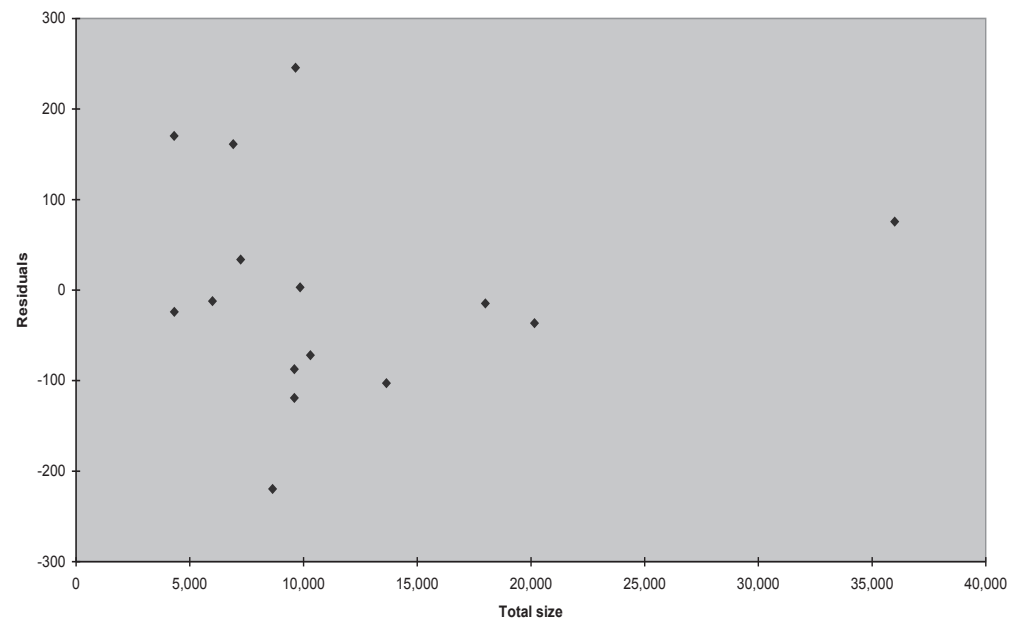

Cycle in days Residual Plot

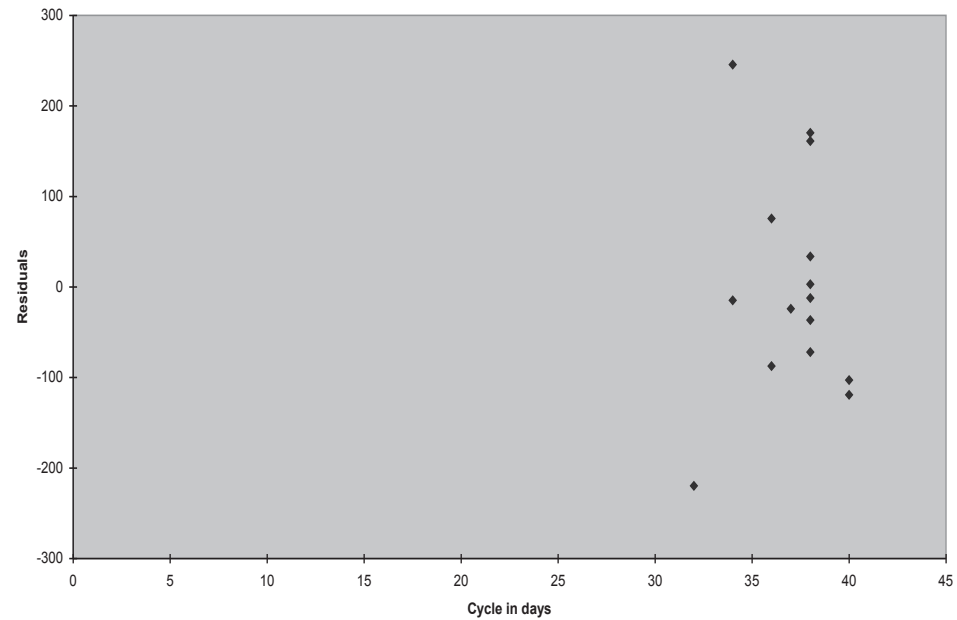

